\title{
Intervention in the Loneliness of the Elderly-What Strategies, Challenges and Rewards?
}

\author{
Manuela Dias ${ }^{1}$, Carla Silva ${ }^{1}$, Ricardo Dias $^{2}$ and Helena Oliveira ${ }^{3}$ \\ 1. Primary Care Unit of Terceira Island-Angra do Heroismo Health Center, Angra do Heroísmo, Terceira Azores 9701-869, Portugal \\ 2. Terceira Island Hospital, Angra do Heroísmo, Terceira, Azores 9700-049 Portugal \\ 3. University of the Azores, College of Nursing, S. Miguel, Azores 9504-538 Portugal
}

Received: December 10, 2014 / Accepted: February 7, 2015 / Published: February 28, 2015.

\begin{abstract}
The new challenges that the phenomenon of demographic aging imposes on society in general, and health services in particular, can impact active and healthy aging. The project was implemented for two years (2012/2013) and aimed to combat loneliness in the elderly, which constitutes an obstacle to healthy and active aging. Decrease the sense of loneliness of individuals from 65 to 84 years of age, the project was made by using the health planning methodology, starting with a descriptive study (health diagnosis of the independent elderly population) followed by the development, implementation and evaluation of a community intervention project, which included home visits to the elderly, assessment of the level of loneliness in two different times (UCLA scale) and various intergenerational activities of social life (dancing, walking, online courses, games...) using a cross-section of partnerships and community involvement. There was a decrease from $62.8 \%$ to $41.9 \%$ in the reported overall feeling of loneliness of independent individuals between the ages of 65 and 84 years of age. There was an increase from $50.0 \%$ to $86.4 \%$ of seniors who now have dreams/life projects. The reduction of social and emotional isolation resulted in the promotion of social networks, which not only encouraged social interaction but also considered the elderly who live alone. The health gains arising from it are evidenced in contributing more proactively and the improvement of the quality of life in the elderly community.
\end{abstract}

Key words: Elderly, health planning, loneliness, active aging.

\section{Introduction}

Several institutions nowadays, including the European Commission and the WHO, have placed emphasis on active aging considering it as a new paradigm for the elderly. Active aging is defined by WHO in 2002 [1] as "a process of optimizing opportunities for health, participation and security in order to enhance the quality of life during aging". This represents a challenge for society in general, for health policy and for the nursing community and public health, in the context of primary prevention and health promotion. This imposes a responsibility to offer the elderly the opportunity to maintain independence and stay active as they age, with further contributions to

Corresponding author: Manuela Dias, Rn, CNSs, research fields: public health, community interventions. E-mail: mmmgdias@gmail.com. society and to face aging as an achievement for humanity.

The transition from adulthood to old age is a process that can cause large changes in the self-esteem and the self-image of these people, who tend to no longer be valued by society, are often seen as a burden and usually required other types of supports. The privation of certain social roles, resulting from the loss of importance and social power in the elderly, often leads to feelings of isolation and loneliness.

Data from the ESS, Round 4 2008/2009 (European Social Survey) revealed that sociability tends to decrease with advancing age, increasing the difficulty in making new friends and to socialize [2], which limits personal relationships and social participation, creating a vicious cycle of exclusion and malaise [3], often leading to feelings of isolation and loneliness that have 
a negative impact on quality of life and the health of the elderly [4] being an obstacle to a healthy and active aging.

Loneliness is strongly related to living alone and social isolation ${ }^{3}$, factors that increase the risk of heart disease, hypertension, alcoholism, drug addiction and mental illnesses such as dementia, too costly for individuals, families and the state [5]; people who live alone, without family or companionship are according to some psychologists, more likely to suffer from physical and mental diseases, their immune system is more vulnerable and more prone to contracting chronic diseases, presenting twice the risk of death than those that remain accompanied [6].

\section{Methodological Notes}

In this work, which does not portray pure research, but rather action research, the methodology of planning in health was used. Considering that it calls for rational use of scarce resources and the coordination of efforts from various socio-economic sectors, in order to achieve the objectives set, in order to reduce the health problems that are considered priority [7].

It is a continuous and dynamic process that involves several stages: Diagnosis of the Situation/Health Diagnosis, Priority Setting, Setting of Objectives, Strategy Selection, Program and Project Development, Project Preparation and Execution Forecast Evaluation, and finally, Implementation and Evaluation [7].

\subsection{1 st Stage}

It started as an academic scope, in 2011, with a health diagnosis, which consisted of a descriptive cross-sectional study of elderly population in the parish of São Mateus da Calheta, Azores, Portugal. Descriptive studies are shown to describe the phenomenon by establishing the characteristics of a population or a sample thereof [8].

The health diagnosis requires a precise knowledge of the health status of the community and the factors that condition, preceding any intention to formulate comprehensive health programs and run them successfully ${ }^{8}$.

Health diagnosis scientifically validated an analytical model that would allow exploration of concepts and their relationship to each other ${ }^{9}$, which characterized the community, identified health resources thereof [9], and identified the health status of the elderly population. Based on indicators of health, documentary research, key informants from the community and systematic data collection, created for this purpose since no systematic information exists in the community under study.

The instrument for data collection was the questionnaire, which focused on the determinants of health for active aging, such as biological, behavioral, psychosocial and material factors. The same was redesigned after the application of pre-test, as well as the respective script.

\subsection{Population and Sample}

According to the 2001 census, the parish of São Mateus da Calheta (Azores-Portugal) had 286 elderly residents, the ages between 65 and 84 years old. A sample of $30 \%$ was random and in parts, assuming the characteristic genre to stratify the population-representing 86 individuals, $51 \mathrm{M}$ European Social Survey and 35F, also sought to respect the proportions of age groups. The characterization of the sample can be observed in Table 1 .

To analyze the data we used the SPSS (Statistical Package for Social Sciences), version 19.0, based on the questionnaire and the analytic model. It was used descriptive statistics to calculate the frequencies and percentages for nominal variables and the Chi-square (study of the distribution in nominal variables) assuming as a statistically significant relationship the $p$ value $\leq 0.05$.

\subsection{Ethical and Deontological Issues}

At the beginning of the interview, all participants 
Table 1 Sample characterization.

\begin{tabular}{lll}
\hline & Absolute frequency $(\mathrm{N}=86)$ & Relative frequency \% \\
\hline Ages & & 33.7 \\
\hline$[65-70]$ & 29 & 25.6 \\
{$[70-75]$} & 22 & 20.9 \\
{$[75-80]$} & 18 & 19.8 \\
{$[80-84]$} & 17 & 59.3 \\
\hline Gender & & 40.7 \\
\hline Male & 51 & 59.3 \\
Female & 35 & 27.0 \\
\hline Marital Status & & 10.5 \\
\hline Married/cohabitating & 51 & 2.3 \\
Widowed & 24 & 33.7 \\
Separated/divorced & 9 & 9.3 \\
Single & 2 & 40.7 \\
\hline Level of education & & 12.8 \\
\hline Cannot read or write & 29 & 2.3 \\
Can read and write & 8 & 1.2 \\
1st cycle (4 years of schooling/Elementary) & 35 & 79.1 \\
2nd cycle (6 years of schooling/some Middle school) & 11 & 14 \\
3rd cycle (9 years of schooling/finish Middle school) & 2 & \\
High school & 1 & \\
\hline Housing & & \\
\hline Own home & 68 & \\
Lives with family & 12 & \\
\hline
\end{tabular}

were informed about the objectives of the study, its purpose and guaranteed anonymity and confidentiality of information, and that participation was voluntary. Informed consent was requested verbally and not in writing, given that it was population with frequent limitations of schooling, as would be proven. The health diagnosis allows trace the epidemiological profile of this population, 49 emerging problems/health needs, of which the authors highlight those listed in Table 2.

\subsection{2nd Stage}

When health needs are broader than the available resources, the need to effectuate choices, set limits, criteria and parameters in order to prioritize what and to whom services and health care will be offered [10], to avoid isolated and ineffective interventions [11].

A pre selection or screening by the working group was made to elect five priority issues to utilize two epidemiological criteria and the magnitude of the vulnerability. Subsequently, these five problems, the authors applied the Hanlon method, whereas enables active participation of the community [12] in decisions about their own health care, permitting as such, an increase to their skills and empowerment, recommendations made in the Charter of Jakarta "People have to be at the center of health promotion action and decision-making processes". When applying the Hanlon method it was used the dynamics of the focus group with formal and informal community leaders.

After being validated by experts in the field the prioritized issue was " $62.8 \%$ of older people experience feelings of loneliness".

\subsection{3rd Stage}

Objectives for an intervention project, with regard to conditions that cause the problem, were traced, namely, 
Table 2 Determinants of health of the sample/results (health diagnosis).

\begin{tabular}{|c|c|c|}
\hline & Absolute frequency $(\mathrm{N}=86)$ & Relative frequency $\%$ \\
\hline \multicolumn{3}{|l|}{ Material determinants } \\
\hline Source of income, pension/retirement & 83 & 96.5 \\
\hline Incomes below the national minimum wage & 48 & 55.8 \\
\hline Perception of insufficient income to needs & 28 & 32.6 \\
\hline Perception of unsafe home & 16 & 18.6 \\
\hline Limited activities for fear of falling & 33 & 38.4 \\
\hline \multicolumn{3}{|l|}{ Psychosocial determinants } \\
\hline No desire for activities of daily living (ADL's) & 13 & 15 \\
\hline Unhappiness & 18 & 20.9 \\
\hline Solitude & 54 & 62.8 \\
\hline No desire to learn & 85 & 98.8 \\
\hline Desire to learn & 14 & 16.5 \\
\hline Does not volunteer time & 78 & 90.6 \\
\hline Available for volunteering & 18 & 23.1 \\
\hline Without dreams and life plans & 43 & 50.0 \\
\hline Living with spouse & 50 & 58.1 \\
\hline Living alone & 17 & 19.8 \\
\hline Prefer to stay at home than go out to socialize & 35 & 40.7 \\
\hline Provides support to the family & 65 & 75.6 \\
\hline No one to turn to & 6 & 7 \\
\hline Victim of fraud or theft & 18 & 20.9 \\
\hline If was a target of violence, would not tell anyone & 9 & 10.5 \\
\hline Spirituality/religiosity important to health & 69 & 80.3 \\
\hline \multicolumn{3}{|l|}{ Behavioral determinants } \\
\hline Inadequate nutrition & 57 & 66.3 \\
\hline Smokes & 13 & 15.0 \\
\hline Number of hours of sleep - 6 to 8 hours each night & 53 & 61.6 \\
\hline Takes medication & 82 & 95.3 \\
\hline Did not receive seasonal flu vaccine in 2011 & 46 & 54.1 \\
\hline Doesn't practice physical activity & 26 & 30.2 \\
\hline Does not do oral health surveillance & 61 & 70.9 \\
\hline \multicolumn{3}{|l|}{ Biological determinants } \\
\hline Rheumatic Diseases & 47 & 54.7 \\
\hline Depression & 9 & 10.5 \\
\hline Urinary incontinence & 22 & 25.6 \\
\hline Perception of difficulty in vision & 38 & 44.2 \\
\hline Perception of difficulties in hearing & 31 & $36 \%$ \\
\hline
\end{tabular}

Note: all seniors who live alone experience loneliness.

the contributing factors (predisposing, reinforcing and facilitators).

\subsubsection{General Objective}

Reduce from $62.8 \%$ to $42.8 \%$ the percentage of seniors who experience feelings of loneliness.

\subsubsection{Specific Objectives}

- Decrease from $100 \%$ to $80 \%$ the feeling of loneliness in people living alone;

- Decrease from $40.7 \%$ to $30.0 \%$ the percentage of seniors who prefer to stay at home instead of socializing;

- Increase from $9.4 \%$ to $20 \%$ the percentage of seniors who provides voluntary services;

- Increase from $1.2 \%$ to $30 \%$ the percentage of seniors who attend continuing education. 


\subsection{4 th, 5th and 6th Stage}

The remaining steps subsequently come together, with the exception of the evaluation that will be further developed in the results chapter.

It was designed as an aggregator intervention project with strategies that respond to the goals set transversely [13] to the three levels of prevention:

Primary-development of various activities in the parish (preventing the feeling of loneliness, social isolation and emotional isolation);

Secondary-identification of older people living alone and assessing levels of loneliness by applying the scale of the UCLA (University of California at Los Angeles), a Portuguese adaptation of the Revised UCLA Loneliness Scale original (Portuguese version consists of 18 items). The responses to each item are made on a Likert scale with four points from never (1) to often (4), obtaining 18 points score as a minimum and 72 points score as a maximum. It does not directly question the subject if he/she "feels loneliness", loneliness is evaluated indirectly;
Tertiary-development of interventions that increased social interaction and social support networks for the elderly who scored greater than 35 utilizing the UCLA scale.

Several partnerships were established with local entities (CSPSMC, UAc-ESEnfAH, JFSMC, USIT-CSAH and CMAH, among others) who worked in a structured, planned and organized way, which proved to be indispensable to the completion of the project.

The interventions and activities that were planned and executed included the creation of a scholarship for intergenerational volunteering, regular visits to the elderly, the participation of the elderly in "story time" and "game time", at the playground and ATL respectively, outdoor walks, yoga classes, dances, visits to places of interest and local festivities, enrichment of knowledge and health education lectures, crafts, computer courses, among others, Table 3.

\section{Results}

Seniors who joined the study reside in SMC, a

Table 3 Interventions and activities developed in the project Com(viver) mais.

\begin{tabular}{|c|c|c|c|}
\hline Main activities & No. of activities & $\begin{array}{l}\text { No of elderly involved } \\
\text { in each activity }\end{array}$ & Partners involved \\
\hline Computer course ( 3 months) & 1 & 10 & CMAH \\
\hline Balls & 7 & 46 & CSPSMC \\
\hline Storytelling & 20 & 9 & CSPSMC \\
\hline Game Time & 20 & 15 & CSPSMC \\
\hline Yoga classes & 18 & 28 & Monitors \\
\hline Home visits & 630 & 21 & $\begin{array}{l}\text { USIT-CSAH } \\
\text { UAc-ESEnfAH } \\
\text { CSPSMC }\end{array}$ \\
\hline Performance of music groups & 1 & 55 & $\begin{array}{l}\text { UAc-ESEnfAH } \\
\text { UAc-ESEnfAH }\end{array}$ \\
\hline Picnic & 1 & 49 & $\begin{array}{l}\text { CSPSMC } \\
\text { JFSMC }\end{array}$ \\
\hline Hydrotherapy & 1 & 10 & Physiotherapist \\
\hline $\begin{array}{l}\text { Visits to places of interest } \\
\text { (disco, cheese factory, museum, bowling...) }\end{array}$ & 10 & 40 & $\begin{array}{l}\text { CSPSMC } \\
\text { JFSMC } \\
\text { UAc-ESEnfAH }\end{array}$ \\
\hline $\begin{array}{l}\text { Sessions of health education } \\
\text { (loneliness, sexuality and emotions ...) }\end{array}$ & 9 & 39 & $\begin{array}{l}\text { UAc-ESEnfAH } \\
\text { USIT-CSAH }\end{array}$ \\
\hline Craft sessions & 36 & 16 & CSPSMC \\
\hline Education lectures for the volunteers & 1 & 6 & \\
\hline Sessions of intellectual stimulation and memory & 32 & 14 & CSPSMC \\
\hline Total & 787 & 358 & \\
\hline
\end{tabular}


Table 4 Results obtained of project evaluation/comparison with the initial results.

\begin{tabular}{llll}
\hline & DCH & 2014 & VARIATION \\
\hline Unhappiness & $20.9 \%$ & $16.4 \%$ & $-4,5 \%$ \\
Education lectures / last two years & $1.2 \%$ & $47.7 \%$ & $+46.5 \%$ \\
Provision of voluntary & $9.4 \%$ & $20.1 \%$ & $+10.7 \%$ \\
Dreams and life projects & $50.0 \%$ & $86.4 \%$ & $+36.4 \%$ \\
Prefer to stay at home than go out to socialize & $40.7 \%$ & $25.9 \%$ & $-14.8 \%$ \\
\hline Feeling of loneliness & & & $-20.9 \%$ \\
\hline Solitude & $62.8 \%$ & $41.9 \%$ & $-5.8 \%$ \\
$\quad$ loneliness every day; & $8.3 \%$ & $2.5 \%$ & $-2.4 \%$ \\
$\quad$ loneliness almost everyday & $8.3 \%$ & $5.9 \%$ & $-5.9 \%$ \\
$\quad$ loneliness sometimes & $23.3 \%$ & $17.4 \%$ & $-6.8 \%$ \\
$\quad$ rarely & $20.9 \%$ & $14.1 \%$ & $-20.4 \%$ \\
Loneliness / elderly who live alone & $100 \%$ & $79.6 \%$ & -5.9 \\
\hline Evaluation of UCLA scale & & & -8.9 \\
\hline$\quad$ Average score in the elderly living alone & 39.3 & 33.4 & 26.5 \\
$\quad$ Average score in the elderly live together & 35.4 & & \\
\hline
\end{tabular}

semi-rural parish council of Angra do Heroismo, and also encompassed the existing old people association. These results stem from the last step, project evaluation, through the calculation of the indicators outlined for the purpose and goals of the project (Table 4).

It can not be said that these results are due only to the execution of the project, since these are sensitive to many external and internal factors dimensions of complex causality, but there was an improvement in the evaluated indicators that attest to the achievement of the objectives proposed.

The overall goal has been achieved, in that the percentage of seniors who experience feelings of loneliness decreased from $62.8 \%$ to $41.9 \%$. Additionally, it was found that there was a reduction in the frequency with which seniors experienced loneliness:

- $5.8 \%$ in the percentage of seniors who experience loneliness every day;

- $2.4 \%$ in the percentage of seniors who experience loneliness almost every day;

- $1.8 \%$ in the percentage of seniors who sometimes experience loneliness.

To achieve the overall objective unequivocally contributed the achievement of specific objectives, the percentage of seniors who experience feelings of loneliness and live alone decreased from $100.0 \%$ to $79.6 \%$. The UCLA scale allowed an accurate measurement in assessing the level of loneliness (score), showing the decrease in mean score, from 39.3 to 33.4 of the elderly who live alone and have been the target of home visits.

The percentage of seniors who prefer to stay at home than go out to socialize decreased from $40.7 \%$ to $25.9 \%$. The percentage of seniors who had education lectures increased from $1.20 \%$ to $47.7 \%$, surpassing by $17.7 \%$ the defined goal. The percentage of seniors who provided volunteer services increased from $9.40 \%$ to $20.1 \%$.

During the calculation of these indicators, it was possible to determine that other health gains emerged: There was a noted increase in happiness, the percentage of seniors who reported not feeling happy decreased from $20.9 \%$ to $16.4 \%$; it was also found that there was an increase from $50.0 \%$ to $86.4 \%$ in the percentage of elderly who have dreams/life projects, as well as a decrease from $40.7 \%$ to $25.9 \%$ of seniors who would rather stay in the house than go out to socialize. It was gratifying to note that the average level of loneliness (score) of the elderly who live together, and that were subject to visitation, also decreased from $35.4 \%$ to $26.5 \%$. 


\section{Discussion of Results}

This work is different from the usual in that it brings together several studies since the initial diagnosis, prioritization with the involvement of the population (through their leaders), implementation of the project and the final evaluation, demonstrating the gains in health for the elderly.

The focus of the project was the prioritized problem-identifying that $62.8 \%$ of the elderly experience feelings of loneliness, a high value compared to other studies. In Finland, 39\% of a sample of 3,915 seniors reported feelings of loneliness [14]. In Portugal, 179 elderly [4] found an average perception of loneliness, according to the UCLA scale of 30.37 , lower than the value recorded in this study, which was 37.4.

Reducing the perception of loneliness resulted in the absence of loneliness in $20.9 \%$ of the elderly in general and in $20.4 \%$ of those living alone, suggesting an improvement in quality of life impact at the various levels. As mentioned earlier, this adversely affects the quality of life for seniors and arises due to a trend in decrease of contacts and social relationships [15]. It also contributes to reducing the risk of occurrence of depression. Loneliness and depression can be reciprocally related, the increased level of loneliness can lead to increased depression and vice versa, and this includes high rates of morbidity and mortality at advanced ages [16] and can be disabling [17]. Depression is the leading cause of disability and the second leading cause of loss of healthy life years, implying very high [4] personal and social costs. A depressed person can manifest cognitive and behavioral changes such as lack of motivation, disturbances in will, disaffection, loss of appetite, somatization, physical pain, irritability, difficulty concentrating, sleep problems, loss of enjoyment of life, physical weakness, difficulty socializing with friends, colleagues and relatives [18]. If left untreated, it can lead to suicide. It is estimated that this disease is associated with the loss of 850 thousand lives per year, more than 1,200 deaths in Portugal. A quarter of all suicides registered in Portugal last year were perpetrated by people over 60 years. Following to the cardiovascular diseases, suicide is the second most frequent cause of death in old age, according to Lia Fernandes, president of the Portuguese Association of Gerontopsychiatry.

Reducing the perception of loneliness also helps to reduce biological effects of loneliness. Studies conducted at the University of Chicago [19] to determine the effects of loneliness reveal that it is directly linked to the hardening of the arteries leading to high blood pressure, inflammation of the body, and also problems related to learning and memory.

As they age, people are faced with new challenges and new demands. Education/Enrichment of their knowledge is therefore one of the means of responding to the challenges the elderly are imposed by age and society, increasing their empowerment. Participation in educational activities is also seen as a key to individual and social success, because it promotes the intellectual, physical, emotional and social [20] welfare.

The strategies outlined to reduce loneliness included the provision of education/enrichment of their knowledge, assuming that these activities provide spaces for recreation and socializing, and represent a preventive strategy analogous to the solitude of Third Age [20] Universities. Education in addition to preventing, also promotes decreased loneliness of older people and social exclusion. In fact, there was an increase from $1.20 \%$ to $47.7 \%$ of the percentage of seniors who attended education/lectures in the last two years (duration of project implementation). Investing in active aging means promoting heath [17] and a consequent increase in health literacy. Studies conducted [21, 22] tend to report lower levels of literacy in the elderly, and support the idea that is a risk factor for health inequalities and access to care.

Education lectures, followed by group discussion, 
are suggested by Fee et al. [23], given the pleasure detected in the elderly when joined and talked about health.

When it comes to volunteering and the elderly, usually thinking of volunteering for older people, this project noted the huge potential that the elderly represent for society as volunteers.

Increasing from $9.40 \%$ to $20.1 \%$ is the percentage of seniors who volunteered services and provided more $10.7 \%$ of individuals the possibility of participation and social prestige among children of kindergarten (storytelling and game), the participation of elderly of the parish (through home visitations), their families and the general population, in order to feel useful to their community contributing to increased self-esteem.

This project provided the regularity of a course on volunteering, fostering the possibility of commitment to a cause; the opportunity to socialize and perform new friendships as well as decreased isolation. Studies in USA [15] reveal that older people participating in voluntary work "predicted better self-rated health, functioning, physical activity and life satisfaction as well as decreased depression and mortality". Several studies analyzed in the literature review conducted by Cattan, Hardill and Hogg [24] point to the positive effect of volunteering, in reducing the risk of depression and decreased depressive symptoms in the elderly. Indeed, it was found that there was a reduction in the level of loneliness in elderly volunteers, higher than the remaining senior citizens.

Happiness can be defined as the degree to which an individual evaluates favorably, the quality of all aspects and dimensions of their life [25]. Seniors consider health as the most important element in the quality of life and its lack as a major cause of unhappiness. Independence is also a major determinant for happiness [26].

A phenomenological analysis in a qualitative study found that adding moments of happiness is related to family and social contact, autonomy and occupational activity, providing sense of personal value, self-esteem and well-being [27]. When it was reduced the percentage of seniors who reported not feeling happy, even if only by $4.5 \%$, it meant that these seniors started to positively evaluate some aspects and dimensions of their life and that may be related to decreased loneliness.

Old age can be a period with projects and achievements, accumulated experience and subsequent training supports the development of projects of life and potential [27]. The pursuit of happiness, having goals and projects all provides a healthy life in old age, with autonomy and independence [18]. The increase of $50.0 \%$ to $86.4 \%$ in the percentage of elderly who now have dreams/life projects is suggestive of an improvement in the welfare of the elderly since happiness, quality of life and autonomy seem to be determining factors also influenced by the existence of life projects or dreams.

It is important for the elderly to be directed towards the future, creating new goals, reviewing the experiences of the past and to be able to look forward with greater maturity for tomorrow [28].

The old people associations and social centers stimulate social interaction, provide a regular appointment, and fill the empty feeling of loneliness, allowing seniors to continue to have goals [28].

The activities described in this project have been developed within and outside the social center, this range aimed to capture the various interests of older people to participate in them, not just the elderly group of the social center, but others in the community. Participation had a great breadth as is displayed in the table and obtained a decrease of $40.7 \%$ to $25.9 \%$ in the percentage of seniors who prefer to stay at home than go out to socialize.

All strategies have contributed to the achievement of a decrease of loneliness in the elderly population, however the home visits occupied a privileged place in intervention in the elderly who live alone and those who preferred to stay home rather than socialize. 


\section{Conclusions}

Population ageing raises many fundamental questions for both societal and health systems. This project describes and exemplifies what is possible and feasible to obtain and demonstrate health gains in the elderly population, by implementing projects embodied by the methodology of health planning, specifically by adopting strategies to combat loneliness that encourage interaction social networks and social support.

\section{References}

[1] Paul, C. 2005. "Envelhecimento Activo e Redes de Suporte Social." Accessed October 2, 2013. http://ler.letras.up.pt/uploads/ficheiros/3732.pdf.

[2] Marques, S. 2011. Discriminação da Terceira Idade. Lisboa: Fundação Francisco Manuel dos Santos.

[3] Fernandes, H. 2007. Solidão em Idosos do Meio Rural do Concelho de Bragança. Porto: Faculdade de Psicologia e Ciências da Educação.

[4] Teixeira, L. 2010. "Solidão, Depressão e Qualidade de vida em Idosos: um Estudo Avaliativo Exploratório e Implementação-Piloto de um Programa de Intervenção." Thesis, Núcleo de Psicologia da Saúde e da Doença.

[5] Sousa, L., Figueiredo, D., and Cerqueira, M. 2004. Envelhecer em Família: Os Cuidados Familiares na Velhice. Porto: Ambar.

[6] Gaul, G. 2010. da Sociedade Austríaca de Cardiologia, citado pela agência EFE.

[7] Imperatori, E., and Giraldes, M. 1982. Metodologia do Planeamento da Saúde: Manual para uso em Serviços Centrais, Regionais e Locais. Lisboa. Obras Avulsas.

[8] Fortin, M. 1999. Processo de Investigação: da Concepção à Realização. Loures: Lusociência.

[9] Martinéz, D. 2007. Profesiones Sanitarias-Conceptos Generales em Atención Primaria Para Enfermería (1 ${ }^{a}$ ed.). Sevilla: Editorial MAD.

[10] Fortes, P. 2008. "Reflexão Bioética Sobre a Priorização e Racionamento DE Cuidados DE Saúde: Entre a Utilidade Social e a Equidade." Cadernos de Saúde Pública 24 (3): 696-701.

[11] Tavares, A. 1990. Métodos e Técnicas de Planeamento em saúde. Lisboa: Departamento de Recursos Humanos da Saúde. Centro de Formação e Aperfeiçoamento Profissional.

[12] Chao, R., and Alvarez, M. 1996. "Diagnóstico Comunitario de la Situación de Salud." Accessed April 24, 2012. http://www.bvs.sld.cu/revistas/mgi/vol12_3_96/mgi1339 6.htm.

[13] Neto, F. 1992. Solidão, Embraço e Amor. Porto: Centro de Psicologia Social.

[14] Savikko, N., Routasalo, P., Tilvis, R., Strandberg, T., and Pitkala, K. 2005. "Predictors and Subjective Causes of Loneliness in an Aged Population." Archives of Gerontology and Geriatrics 41: 223-33.

[15] von Bonsdorff, M. B., and Rantanen, T. 2011. "Benefits of Formal Voluntary Work among Older People." A Review. Aging Clin Exp Res 23: 162-9.

[16] Martins, R. 2008. A depressão no idoso. Millenium Revista do ISPV. Accessed April 20, 2012. http://www.ipv.pt/millenium/millenium34/.

[17] Zimerman, G. 2000. Velhice, Aspectos Biopsicossociais. Porto Alegre: Artemed Editora.

[18] Cacioppo, J., and Patrick, W. 2009. Abrir a Porta: A Importância do Afeto e da Sociabilidade na Nossa Vida. Estrela Polar.

[19] Hammond, C. 2004. "Impacts of Lifelong Learning upon Emotional Resilience, Psychological and Mental Health: Fieldwork Evidence." Oxford Review of Education 30 (4): 551-68.

[20] Monteiro, H., and Neto, F. 2008. Universidades da Terceira Idade: Da Solidão aos Motivos Para a Sua frequêNcia. Oliveira de Azeméis: Livpsic.

[21] Kutner, M. 2006. The Health Literacy of America's Adults: Results From the 2003 National Assessment of Adult Literacy (NCES 2006-483). Washington, D.C.: National Center for Education Statistics.

[22] Rootman, I., and Ronson, B. 2005. "Literacy and Health Research in Canada: Where Have We Been and Where Should We Go?" Canadian Journal of Public Health 96 (Supplément 2): S62-S77.

[23] FEE, L. 1999. Assessing Older People's Health and Social Needs: Qualitative Research Investigating Health Beliefs and Social Factors Relevant to Older People'S Health. London: Health Education Authority.

[24] Cattan, M., Hogg E., and Hardill I. 2011. "Improving Quality of Life in Ageing Populations: What can Volunteering Do?" Maturitas 70: 328-32. Accessed November 13, 2013. http://www.maturitas.org/article/S0378-5122(11)00319-7 /fulltext.

[25] Veenhoven, R. 1992. "Questions on happiness." In: Happiness in Nations. Studies in Socio-cultural Transformation, edited by Veenhoven R. Rotterdam: Erasmus University.

[26] Joia, L., Ruiz, T., and Donalisio, M. 2007. "Condições Associadas ao Grau de Satisfação com a Vida Entre a População de Idosos." Revista de Saúde Pública 41 (1): 131-8. Accessed September 30, 2014. 
http://www.scielo.br/scielo.php?script=sci_arttext\&pid=S 0034-89102007000100018\&lng=en\&tlng=pt. $10.1590 / \mathrm{S} 0034-89102007000100018$.

[27] Luz, M., and Amatuzzi, M. 2008. "Vivências de Felicidade de Pessoas Idosas." Estudos de Psicologia (Campinas) 25 (2): 303-7. Accessed September 30, 2014. http://www.scielo.br/scielo.php?script=sci_arttext\&pid=S
0103-166X2008000200014\&lng=en\&tlng=pt. 10.1590/S0103-166X2008000200014.

[28] Santos, G., and Vaz, C. 2008. "Grupos da Terceira Idade, Interação e Participação Social.” In Psicologia e práticas sociais, edited by Zanella, A., Siqueira, M. J., Shuellier, L. A., and Molon, S. Available from SciELO Books http://books.scielo.org. 